\title{
In vivo Inhibition of Lung Cancer by GRN163L: A Novel Human Telomerase Inhibitor
}

\author{
Z. Gunnur Dikmen, ${ }^{1,2}$ Ginelle C. Gellert, ${ }^{2}$ Shalmica Jackson, ${ }^{2}$ Sergei Gryaznov, ${ }^{4}$ \\ Robert Tressler, ${ }^{4}$ Pakize Dogan, ${ }^{1}$ Woodring E. Wright, ${ }^{2}$ and Jerry W. Shay ${ }^{2,3}$ \\ ${ }^{1}$ University of Hacettepe, Faculty of Medicine, Department of Biochemistry, Ankara, Turkey; ${ }^{2}$ University of Texas Southwestern \\ Medical Center, Department of Cell Biology and ${ }^{3}$ Harold Simmons Comprehensive Cancer Center, Dallas, Texas; \\ and ${ }^{4}$ Geron Corporation, Menlo Park, California
}

\begin{abstract}
Differential regulation of telomerase activity in normal and tumor cells provides a rationale for the design of new classes of telomerase inhibitors. The telomerase enzyme complex presents multiple potential sites for the development of inhibitors. GRN163L, a telomerase enzyme antagonist, is a lipid-modified 13-mer oligonucleotide $\mathrm{N3}^{\prime} \rightarrow \mathrm{P5}^{\prime}$-thiophosphoramidate, complementary to the template region of telomerase RNA (hTR). We evaluated both the in vitro and in vivo effects of GRN163L using A549-luciferase (A549Luc) human lung cancer cells expressing a luciferase reporter. GRN163L $(1 \mu \mathrm{mol} / \mathrm{L})$ effectively inhibits telomerase activity of A549-Luc cells, resulting in progressive telomere shortening. GRN163L treatment also reduces colony formation in soft agar assays. Surprisingly, after only 1 week of treatment with GRN163L, A549-Luc cells were unable to form robust colonies in the clonal efficiency assay, whereas the mismatch control compound had no effect. Finally, we show that in vivo treatment with GRN163L is effective in preventing lung metastases in xenograft animal models. These in vitro and in vivo data support the development of GRN163L as a therapeutic for the treatment of cancer. (Cancer Res 2005; 65(17): 7866-73)
\end{abstract}

\section{Introduction}

Telomeres are unique DNA structures located at the ends of eukaryotic chromosomes. In humans, they are initially composed of $\sim 15$ to $20 \mathrm{kbp}$ of hexameric TTAGGG double-stranded DNA repeats followed by a single-strand overhang of the 3 -G-rich strand that is inserted back into the double-strand DNA in a lariat-like structure called the t-loop (1). Telomerase is a ribonucleoprotein complex that elongates telomeric DNA by adding TTAGGG repeats to the chromosomes. This enzyme plays a key role in the cellular immortalization of cancers (2). One of the major components of telomerase uses the reverse transcriptase protein subunit (hTERT), to add repeats onto the single-stranded telomere end. The second major component of telomerase is an endogenous 455-nucleotide RNA subunit (hTR) which is closely associated with hTERT and with other proteins $(3,4)$. As tumor cells divide, telomerase is required for the continued proliferation of tumor cells to compensate for the loss of telomeres resulting from the end replication problem, exonuclease processing of $5^{\prime}$ ends of DNA, as

Requests for reprints: Jerry W. Shay, Department of Cell Biology, University of Texas Southwestern Medical Center, 5323 Harry Hines Boulevard, Dallas, TX 77030. Phone: 214-648-3282; Fax: 214-646-8694; E-mail: Jerry.Shay@UTSOUTHWESTERN.EDU. (C)2005 American Association for Cancer Research.

doi:10.1158/0008-5472.CAN-05-1215 well as by shortening due to oxidative stress $(5,6)$. In the absence of telomerase, chromosome ends shorten with each cell division, eventually resulting in growth arrest. This telomere lengthinitiated growth arrest is termed replicative senescence and is postulated to be a tumor-protective mechanism in vivo (7-9).

Telomerase is active in $85 \%$ to $90 \%$ of all human tumors but not in normal somatic cells with the exception of germ line and select progenitor cell populations $(10,11)$. It has been suggested that tumor cells have unlimited proliferative potential as a consequence of the reactivation or up-regulation of telomerase. The activation of telomerase by itself does not promote carcinogenesis, it only allows a cell to continue dividing and attain proliferative immortality, a necessary step for conversion of normal human cells into tumor cells $(12,13)$. Although tumor cells express telomerase, they typically have short but stable telomere length, whereas normal cells do not express telomerase and have long, slowly shortening telomeres. These differences between cancer and normal cells make cancer cells more sensitive to telomerase inhibitors and may allow for a substantial therapeutic window for telomerase inhibition based treatments which makes telomerase a potentially universal and relatively safe anticancer target (14).

Several classes of telomerase inhibitors have been designed and evaluated, such as direct small-molecule inhibitors (15-18), compounds targeting putative telomeric DNA G-quadruplex structures (19-21), dominant-negative hTERT genes (22), antisense oligonucleotides targeting hTR or hTERT mRNA (23), ribozymes targeting hTR (24) or hTERT mRNA (25), and hTR-directed PNA oligonucleotides (26). Thirteen-mer oligonucleotides $\mathrm{N}^{\prime} \rightarrow \mathrm{P}^{\prime}$ phosphoramidates and $\mathrm{N}^{\prime} \rightarrow \mathrm{P}^{\prime}$-thio-phosphoramidates have also been shown to be effective telomerase inhibitors in cultured cells (27).

Telomerase RNA (hTR) contains an 11-nucleotide-long template region for binding to and extending telomeric DNA substrates that is easily accessible for hybridization with complementary oligonucleotides. Thus, hTR represents an attractive target for oligonucleotide based anti-telomerase therapies (28). Unlike antisense oligonucleotides that inhibit translation by binding to mRNA, the hTR addressed oligonucleotide functions as a "traditional" competitive enzyme inhibitor that binds and blocks the active site of the enzyme (29).

In oligonucleotide $\mathrm{N}^{\prime} \rightarrow \mathrm{P} 5^{\prime}$-phosphoramidates, the $3^{\prime}$ amino group is substituted for $3^{\prime}$-oxygen in the $2^{\prime}$-deoxyribose ring, and the nucleosides are linked together via phosphoramidate monoester linkages instead of natural phosphodiester counterparts (30). Replacing the 3 -oxygen by an amino group introduces a moiety into the oligonucleotide backbone that can act as both hydrogen bond donor and acceptor $(31,32)$. Oligonucleotide $\mathrm{N}^{\prime}$ $\rightarrow \mathrm{P} 5^{\prime}$-phosphoramidates are ionized and negatively charged at neutral $\mathrm{pH}$, resistant to nuclease degradation, and display high 
specificity and stability for DNA and RNA targets, with a relatively low affinity for proteins (33). Duplex formation by the oligonucleotide phosphoramidates is a highly sequence-specific process that is guided by Watson-Crick hydrogen bond formation. Moreover, their duplexes with complementary RNA strands are not substrates for RNase $\mathrm{H}$ catalyzed hydrolysis in vitro. These properties make the compounds attractive candidates for various biochemical and biological applications. The novel telomerase inhibitor GRN163L is a lipidated 13-mer oligonucleotide $\mathrm{N3}^{\prime} \rightarrow$ P5'-thio-phosphoramidate complementary to the RNA template region of hTR that acts as a "telomerase template antagonist" and is a potent enzymatic inhibitor of telomerase that does not use an antisense mechanism of action for telomerase inhibition. Oligonucleotide $\mathrm{N}^{\prime} \rightarrow$ P5'-thio-phosphoramidates were synthesized using phosphoramidate transfer methodology consisting of detritylation, coupling, capping, and sulfurization steps, starting from a palmitoyl (C16) lipid group added to the $5^{\prime}$ terminus of the oligonucleotide via an aminoglycerol linker (34).

High RNA binding affinity of the phosphoramidates and protein interactive capabilities of oligonucleotide phosphorothioates were combined in $\mathrm{N} 3^{\prime} \rightarrow \mathrm{P}^{\prime}$-thio-phosphoramidates. The structure of these compounds allow them to bind in a sequence specific manner to the targeted template region of hTR and create secondary stabilizing interactions with the regions of hTERT in proximity to the hTR-hybridized oligonucleotide via PS-groupsprotein contacts. Additionally, $\mathrm{N} 3^{\prime} \rightarrow \mathrm{P}^{\prime}$-thio-phosphoramidates are more acid resistant than the parent phosphoramidate oligomers (by 10- to 100-fold), likely due to the presence of an alternative basic site $(-\mathrm{P}=\mathrm{S})$ in the linking thio-phosphoramidate group $(34,35)$. The presence of the $5^{\prime}$ - lipid group increases cellular uptake of these compounds.

Lung cancer is the leading worldwide cause of cancer death and the incidence of adenocarcinoma, a subtype of non-small cell lung cancer, is increasing. The survival rate of patients with lung adenocarcinoma is poor even when treatment is given in the early stage of the disease, because most patients already have disease that has metastasized (36-38).

The aim of our current study was to examine the effects of GRN163L on A549-luciferase (A549-Luc) cells (a human adenocarcinoma cell line) both in vitro and in vivo. We show that GRN163L inhibits telomerase activity in a dose- and sequence-dependent manner in A549-Luc cells at pharmacologically relevant doses and that inhibition results in progressive telomeric shortening. Cells treated with GRN163L rapidly lost their ability to form robust colonies in culture and displayed reduced colony formation in soft agar assays, whereas mismatch treatments had no effect in these assays. Moreover, in vivo studies showed that GRN163L administration prevents formation of lung tumors in this experimental xenograft metastasis model. We consequently conclude that lipidated GRN163L oligonucleotide $\mathrm{N}^{\prime} \rightarrow \mathrm{P}^{\prime}$-thio-phosphoramidate GRN163L is an efficient telomerase inhibitor. It is being developed as a safe and specific anticancer agent that might be used after surgery, or in combination with chemotherapy or radiotherapy to inhibit the outgrowth of residual cancer cells and treat micrometastatic disease.

\section{Materials and Methods}

Generation of A549-luciferase cells. A549 cells were obtained from the American Type Culture Collection (Manassas, VA) and grown in F12 media (Life Technologies, Gaithersburg, MD) containing 5\% fetal bovine serum
(FBS, Invitrogen, San Diego, CA) without antibiotics. The A549-Luc lung cancer cell line was established using a lentivirus encoding the luciferase gene driven by a ubiquitin promoter. Lentivirus was produced in 293T cells grown in DMEM plus $10 \% \mathrm{FBS}$ at $37^{\circ} \mathrm{C}, 5 \% \mathrm{CO}_{2}$. The lentiviral packaging vectors (CW-GagPol, CMW-Rev, CMV-VSV-G) were cotransfected along with lenti-Ub-luc into 293T cells using Fugene 6 (Roche Biosciences, Nutley, NJ) overnight ( $\sim 14-16$ hours) at $37^{\circ} \mathrm{C}$. Virus-containing medium was collected and filtered ( 0.45 micron) after 24,36 , and 48 hours and replaced with fresh culture medium at each time point. The A549 cells were infected with the virus-containing medium supplemented with $10 \mu \mathrm{g} / \mathrm{mL}$ of DEAE-Dextran. After infection, the virus-containing media was replaced with fresh F12 medium to allow the cells to recover for 24 to 48 hours. The cells were then plated at $3 \times 10^{4}$ per 10-cm dish and placed under selection of G418 at 500 $\mu \mathrm{g} / \mathrm{mL}$ for 2 weeks.

Short-term cell culture studies. The effects of GRN163L on telomerase activity and cellular morphology were tested by short-term treatments. A549-Luc cells were treated at various doses $(4 \mu \mathrm{mol} / \mathrm{L}$ to $250 \mathrm{nmol} / \mathrm{L})$ of the drug and cells were collected for telomeric repeat amplification protocol (TRAP) assay after $24,48,72$, and 96 hours of treatment. In addition, cells treated with GRN163L (5'-Palm-TAGGGTTAGACAA-NH $\left.{ }_{2}-3^{\prime}\right)$ and mismatch oligonucleotide (5'-Palm-TAGGTGTAAGCAA- $\left.\mathrm{NH}_{2}-3\right)$ were examined for morphologic changes after 24, 48, 72, and 96 hours of treatment $($ Palm $=$ Palmitoyl).

Cellular uptake of ${ }^{35} \mathrm{~S}$-labeled GRN163L. Pulse chase experiments were conducted to determine the cellular uptake of ${ }^{35}$ S-labeled GRN163L by A549-Luc cells. Control A549-Luc cells $\left(5 \times 10^{4}\right.$ per well in 6-well plates) were incubated with $10 \mu \mathrm{mol} / \mathrm{L}$ GRN163L, whereas the treatment group was incubated with $10 \mu \mathrm{mol} / \mathrm{L}$ GRN163L $+10 \mu \mathrm{Ci}{ }^{35} \mathrm{~S}$-labeled GRN163L in vitro. In pulse experiments, the medium was removed, and plates of cells were washed with PBS thrice and harvested by scraping after the addition of $1 \%$ Triton X-100 at 24 or 72 hours after incubation with radiolabeled GRN163L. In chase experiments, after 3 days of incubation with radiolabeled GRN163L, cells were washed with PBS thrice and refed with fresh media. Plates of cells were then harvested by scraping after addition of $1 \%$ Triton $\mathrm{X}-100$ after 1,2 , or 3 days of incubation in the absence of ${ }^{35}$ S-labeled GRN163L. ${ }^{35}$ S radioactivity was quantitated by standard liquid scintillation counting methods.

Long-term cell culture studies. For long-term treatment, A549-Luc cells $\left(1 \times 10^{5}\right.$ per $10-\mathrm{cm}$ dish $)$ were fed GRN163L $(1 \mu \mathrm{mol} / \mathrm{L})$ containing medium every 3 days. The cells were counted to determine population doublings and replated every week in the presence of fresh drug during the course of 12 weeks of treatment. Population doublings were calculated as $\log$ (the number of cells collected / the number of cells plated) / $\log 2$. Additionally, during the passage of the cells, treated and untreated cells were plated for clonal efficiency and soft agar assays.

Telomeric repeat amplification protocol. Cells $\left(1 \times 10^{5}\right)$ were collected and lysed in $40 \mu \mathrm{L} \mathrm{NP40} \mathrm{lysis} \mathrm{buffer} \mathrm{[10} \mathrm{mmol/L} \mathrm{Tris-} \mathrm{HCl}(\mathrm{pH}$ 8.0), $1.0 \mathrm{mmol} / \mathrm{L} \mathrm{MgCl}_{2}, 1 \mathrm{mmol} / \mathrm{L}$ EDTA, $1 \% \mathrm{NP} 40,0.25 \mathrm{mmol} / \mathrm{L}$ sodium deoxycholate, $10 \%$ glycerol, $150 \mathrm{mmol} / \mathrm{L} \mathrm{NaCl}, 5 \mathrm{mmol} / \mathrm{L} \beta$-mercaptoethanol, $0.1 \mathrm{mmol} / \mathrm{L}$ AEBSF] for 30 minutes on ice. One microliter of total cellular lysate (2,500 cells) was used for each reaction. For tissue samples, 50-mg tissue was homogenized with NP40 lysis buffer, the protein concentrations of the samples were determined by using bicinchoninic acid kit and $3 \mu \mathrm{g} / \mu \mathrm{L}$ was used. Samples were analyzed with TRAP-eze kit reagents according to the manufacturer's instructions using 30 minutes of telomerase extension at $30^{\circ} \mathrm{C}$, and inactivating telomerase at $94^{\circ} \mathrm{C}$ for 90 seconds. The extension products were amplified by 28 PCR cycles $\left(94^{\circ} \mathrm{C}\right.$ for 30 seconds, $52^{\circ} \mathrm{C}$ for 30 seconds, $72^{\circ} \mathrm{C}$ for 45 seconds) in the presence of a Cy5-labeled TS primer (5'-Cy5-AATCCGTCGAGCAGAGTT; Integrated DNA Technologies, Inc., Coralville, IA). A standard batch of H1299 lung cancer cell line was used as a positive control and lysis buffer was used as negative control for each run. PCR samples $(20 \mu \mathrm{L})$ were analyzed on a $10 \%$ nondenaturing acrylamide gel in $0.5 \times$ Trisborate EDTA at $250 \mathrm{~V}$ for 2.5 hours. Gels were scanned using a STORM 860 PhosphorImager scanner system (Molecular Dynamics, Sunnyvale, CA). Activity was quantitated by dividing the intensity of the extension products by the internal standard. 
Telomere length (terminal restriction fragment) assay. Cell pellets $\left(1 \times 10^{6}\right)$ were resuspended in quick prep lysis buffer $[10 \mathrm{mmol} / \mathrm{L}$ Tris$\mathrm{HCl}(\mathrm{pH} 8.0), 100 \mathrm{mmol} / \mathrm{L} \mathrm{NaCl}, 100 \mathrm{mmol} / \mathrm{L}$ EDTA (pH 8.0)]. After addition of Triton X-100 (1\%) and proteinase $\mathrm{K}(2 \mathrm{mg} / \mathrm{mL})$, samples were incubated at $55^{\circ} \mathrm{C}$ for 2 hours followed by inactivation of proteinase $\mathrm{K}$ for 30 minutes at $70^{\circ} \mathrm{C}$ and dialysis in $10 \mathrm{mmol} / \mathrm{L}$ Tris- $\mathrm{HCl}(\mathrm{pH} 7.5)$ and $1 \mathrm{mmol} / \mathrm{L}$ EDTA $(\mathrm{pH} 8.0)$ at $4^{\circ} \mathrm{C}$ overnight. Genomic DNA was digested with a six-restriction-enzyme mix (1 unit/ $\mu \mathrm{g}$ each of AluI, CfoI, HaeIII, HinfI, $M s p \mathrm{I}$, and RsaI; Boehringer Mannheim, Indianapolis, IN) and the digested DNA was separated on a $0.7 \%$ agarose gel in $1 \times$ TAE buffer $[0.04 \mathrm{~mol} / \mathrm{L}$ Tris-acetate, $0.002 \mathrm{~mol} / \mathrm{L}$ EDTA ( $\mathrm{pH}$ 7.6)]. The terminal restriction fragment (TRF) gel was denatured for 20 minutes in $0.5 \mathrm{~mol} / \mathrm{L} \mathrm{NaOH}$, $1.5 \mathrm{~mol} / \mathrm{L} \mathrm{NaCl}$, rinsed with distilled $\mathrm{H}_{2} 0$ for 10 minutes, and dried on Whatman 3MM paper under vacuum for 1 hour at $55^{\circ} \mathrm{C}$. The gel was neutralized for 15 minutes in $1.5 \mathrm{~mol} / \mathrm{L} \mathrm{NaCl}, 0.5 \mathrm{~mol} / \mathrm{L}$ Tris- $\mathrm{HCl}(\mathrm{pH} 8.0)$ and probed with a radiolabeled telomeric probe (CCCTAA) $)_{4}$ for 16 hours at $42^{\circ} \mathrm{C}$ in $5 \times \mathrm{SSC}$ buffer, $5 \times$ Denhardt's solution, $10 \mathrm{mmol} / \mathrm{L} \mathrm{Na}_{2} \mathrm{HPO}_{4}$, and $1 \mathrm{mmol} / \mathrm{L} \mathrm{Na}_{2} \mathrm{H}_{2} \mathrm{P}_{2} \mathrm{O}_{7}$. The gel was then washed twice with $0.1 \times \mathrm{SSC}$ at room temperature for 15 minutes, exposed to a PhosphorImager screen overnight, and analyzed using a STORM 860 PhosphorImager (Molecular Dynamics).

Clonal efficiency assay. Untreated control cells and pretreated A549Luc cells $(1 \mu \mathrm{mol} / \mathrm{L}$ GRN163L) were plated at low density (500 cells per 10-cm plate) in F12 media in the absence and presence of GRN163L $(1 \mu \mathrm{mol} / \mathrm{L})$ on day 0 . The cells were fed with fresh medium and treated with or without GRN163L $(1 \mu \mathrm{mol} / \mathrm{L})$ on day 5 . The pictures were taken at various time points using an inverted microscope (Ziess, Inc., Jena, Germany). Cells were then washed with PBS; the colonies were fixed (70\% alcohol, 10 minutes) and stained with Giemsa (20\%, 1 hour).

Soft agar assay. Twelve-well culture plates were covered with a layer of $0.5 \%$ agar in medium supplemented with $20 \%$ FBS to prevent the attachment of the cells to the plastic substratum. Cell suspensions (500 cells per well) of the controls and pretreated cells ( $1 \mu \mathrm{mol} / \mathrm{L}$ GRN163L) were prepared in $0.3 \%$ agar and poured into 12 -well plates. The plates were incubated at $37^{\circ} \mathrm{C}$ in a humid atmosphere of $5 \% \mathrm{CO}_{2}$ for 2 weeks until colonies appeared. The colonies were stained with 3-(4,5-dimethyl-2thiazolyl)2,5-diphenyl- $2 H$-tetrazolium bromide $(1-2 \mathrm{mg} / \mathrm{mL})$ and counted.

Biodistribution of ${ }^{35} \mathrm{~S}$-labeled GRN163L in mouse tissues. For the in vivo biodistribution experiments, ${ }^{35} \mathrm{~S}-\mathrm{GRN} 163 \mathrm{~L}(1 \mu \mathrm{Ci})+\mathrm{GRN} 163 \mathrm{~L}$
( $5 \mathrm{mg} / \mathrm{kg}$ ) was injected i.v. into nude mice bearing human lung tumors and healthy control mice. Mice were sacrificed after 24 and 72 hours and various tissues were collected for drug distribution and telomerase activity (TRAP assay).

Xenograft mice experiments. Immunodeficient mice $(\mathrm{nu} / \mathrm{nu}$; Harlan Sprague-Dawley, Inc., Indianapolis, IN) were maintained in pathogen free conditions within the animal resources center (ARC) at the University of Texas Southwestern Medical Center and treated according to ARC and IACUC guidelines. Mice were irradiated with $3.5 \mathrm{~Gy}{ }^{137} \mathrm{Cs} 18$ to 24 hours before tail vein injection with A549-Luc cells. The cell viability of A549Luc cells was checked with trypan blue and $1 \times 10^{6}$ cells were prepared in $100 \mu \mathrm{L}$ sterile $1 \times$ PBS just before tail vein injection.

In vivo experiments were done using two different GRN163L treatment regimens. In the first regimen, A549-Luc cells were pretreated with GRN163L $(1 \mu \mathrm{mol} / \mathrm{L})$ in vitro for 3 weeks and injected $\left(1 \times 10^{6}\right)$ into eight nude mice by tail vein. The animals $(n=4)$ were treated with i.p. GRN163L $(5 \mathrm{mg} / \mathrm{kg}$ ) every 3 days for 3 weeks and imaged by a light emission tomography system (LETS). At the end of the experiment, animals were sacrificed with $\mathrm{CO}_{2}$, India ink (15\%) was injected through the trachea and the lungs were fixed in Fekete's solution $(100 \mathrm{~mL}$ of $70 \%$ alcohol, $10 \mathrm{~mL}$ formalin, and $5 \mathrm{~mL}$ glacial acetic acid) at room temperature.

In the second regimen, A549-Luc cells $\left(1 \times 10^{6}\right)$ were injected into nude mice $(n=9)$ without in vitro pretreatment with GRN163L. The animals were given different doses of GRN163L (three mice with $5 \mathrm{mg} / \mathrm{kg}$, three mice with $15 \mathrm{mg} / \mathrm{kg}$ ) every 3 days for 3 weeks. Both the control and the treatment groups were imaged by LETS.

Light emission tomography system.

$$
\begin{aligned}
& \mathrm{ATP}+\mathrm{D}-\text { luciferin }+\mathrm{O}_{2} \\
& \stackrel{\text { Luciferase }}{\longrightarrow} \text { Oxyluciferin }+\mathrm{AMP}+\mathrm{Ppi}+\mathrm{CO}_{2}+\text { light }
\end{aligned}
$$

The enzyme and substrate coupling causes photon-releasing chemical reactions, and the light produced ranges from 400 to $620 \mathrm{~nm}$ and can be detected by a CCD camera [charge-couple device, Scientific Imaging Technologies, Inc., Tigard, OR (SITe) SI-032AB CCD]. LETS is a novel optical imaging system that combines the features of tomography and CCD cameras, being designed to measure the light quantitatively escaping the

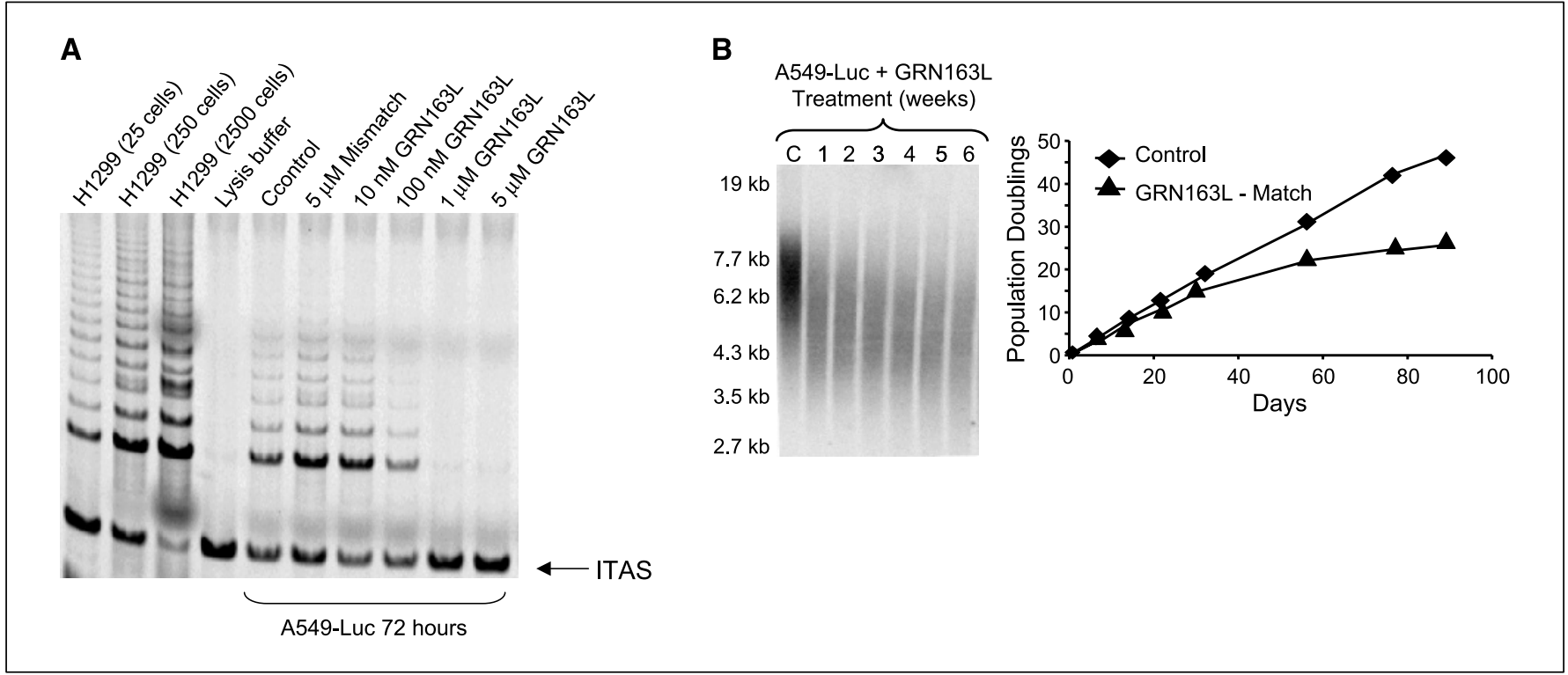

Figure 1. A, inhibition of telomerase activity of A549-Luc cells following different doses of GRN163L for 72 hours. Lanes 1-3, H1299 (25, 250, and 2,500 cells); lane 4, negative control (lysis buffer); lane 5, untreated A549 cells; lane 6, A549+5 $\mu \mathrm{mol} / \mathrm{L}$ mismatch; Lanes 7-10, A549 + 10, $100 \mathrm{nmol} / \mathrm{L}, 1$ or $5 \mu \mathrm{mol} / \mathrm{L}$ GRN163L.

$B$, reduction in telomere length of A549-Luc cells and replicative potential of A549-Luc cells after GRN163L (1 $\mu$ mol/L) treatment. A549-Luc cells cultured in medium without GRN163L ( $\bullet$ and A549-Luc cells cultured in medium containing $1 \mu \mathrm{mol} / \mathrm{L}$ GRN163L (४). 


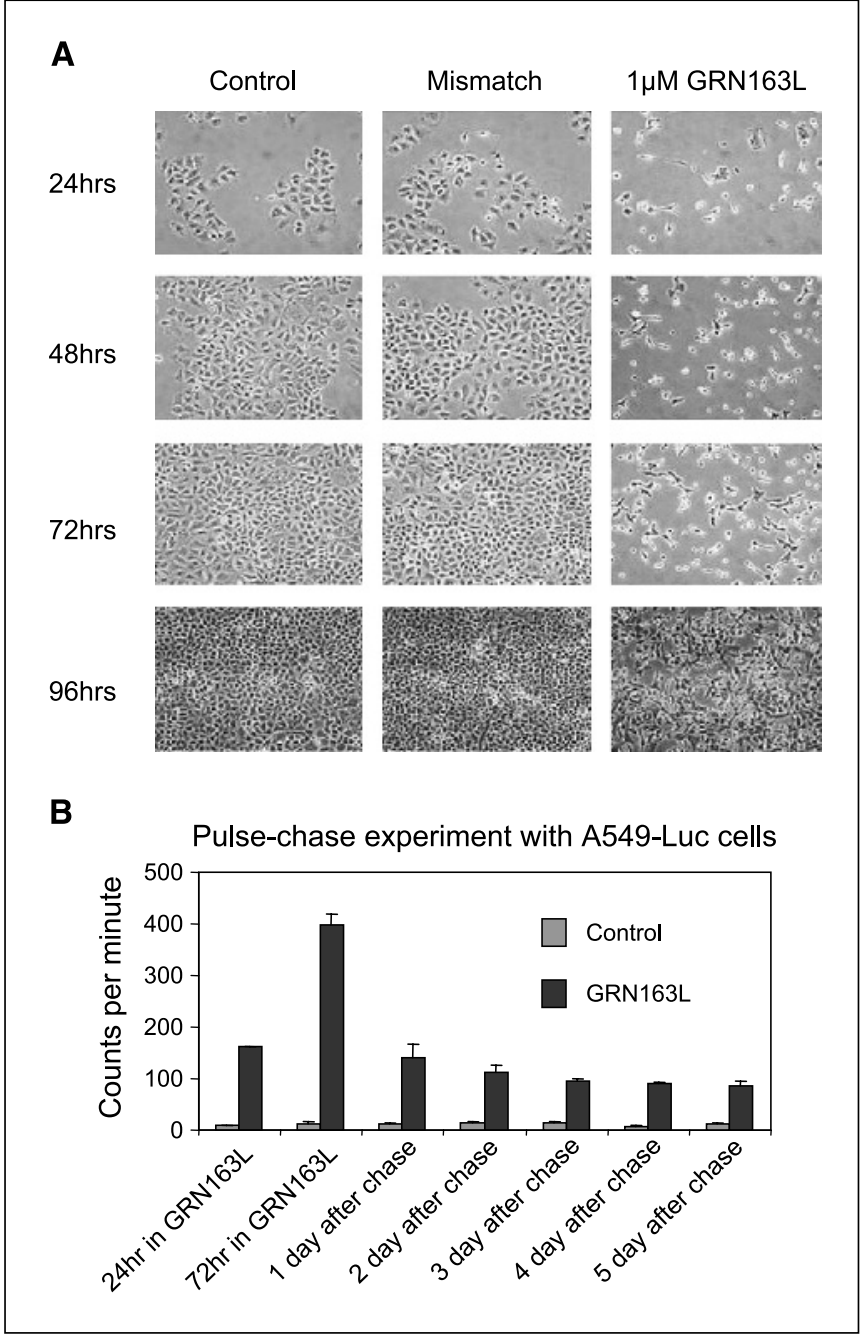

Figure 2. $A$, morphologic changes during treatment for 4 days with $1 \mu \mathrm{mol} / \mathrm{L}$ GRN163L but not with mismatch control. $B$, cellular uptake of ${ }^{35} \mathrm{~S}-\mathrm{GRN} 163 \mathrm{~L}$ $(10 \mu \mathrm{Ci})+$ GRN163L $(10 \mu \mathrm{mol} / \mathrm{L})$ by A549-Luc cells, 24 and 72 hours after exposure to the drug and daily following feeding in drug-free medium (chase).

body over a complete set of angles. Multiple CCD cameras permit the simultaneous acquisition of data at different orientations around the body. A rotational gantry permits motions around a fixed axis approximately coincident with the axis of the body so that the CCD images span a truncated cylindrical surface. The CCD element is chosen so as to have high sensitivity with little variation over a large portion of the visible light spectrum. Light sensitive D-Luciferin substrate (Biosynth, Neperville, IL) was injected $(450 \mathrm{mg} / \mathrm{kg})$ i.p. just before isofluran $(1.5 \%)$ anesthesia. Images were taken for 10 minutes starting 3 minutes after D-luciferin injection. Signal intensity was quantified as the sum of all detected photon counts within the region of interest after subtraction of background luminescence, using the software program (Igor Pro).

\section{Results}

Short-term GRN163L treatment in vitro. Telomerase activity was reduced to nearly undetectable levels within 3 to 4 days after addition of GRN163L $(1 \mu \mathrm{mol} / \mathrm{L})$, whereas a mismatch control compound $(1 \mu \mathrm{mol} / \mathrm{L})$ had no effect on enzyme activity. Figure $1 A$ shows the dose dependent inhibition of telomerase activity in A549-Luc cells following GRN163L $(1 \mu \mathrm{mol} / \mathrm{L})$ treatment, whereas
Fig. $1 B$ shows the telomere length changes and population growth kinetics over 6 weeks. If the cells were treated with a single dose of GRN163L $(1 \mu \mathrm{mol} / \mathrm{L})$, the enzyme activity begins to recover within 3 days (data not shown). This is likely due to dilution of the inhibitor as the cell population increases because we have no experimental evidence suggesting degradation of GRN163L in vitro (data not shown).

The control untreated, mismatch, and GRN163L-treated A549Luc cells show similar growth rates over a treatment period of 2 weeks (Fig. $1 B$ ), but some morphologic changes are observed in the GRN163L $(1 \mu \mathrm{mol} / \mathrm{L})$ treatment group. Figure $2 A$ shows the morphologic changes after GRN163L $(1 \mu \mathrm{mol} / \mathrm{L})$ treatment for 96 hours, whereas no significant changes were observed after a similar period of treatment with mismatch $(1 \mu \mathrm{mol} / \mathrm{L})$ compound.

The results of pulse-chase experiments were consistent with the TRAP analysis. The highest concentration of ${ }^{35} \mathrm{~S}$-labeled GRN163L was measured 72 hours after addition of the drug, the time point when telomerase inhibition occurs (Fig. 2B). After a single dose of the inhibitor, intracellular levels of GRN163L decreased gradually with cell division.

Long-term GRN163L treatment in vitro. Because $1 \mu \mathrm{mol} / \mathrm{L}$ GRN163L almost completely inhibited telomerase activity of A549Luc cells within 72 hours, we used this concentration for the longterm treatment studies, which continued for 12 weeks. Addition of $1 \mu \mathrm{mol} / \mathrm{L}$ GRN163L to A549-Luc cells every 3 days caused a decrease in cell growth rate after 3 to 4 weeks treatment (Fig. $1 B$ ). By the end of the experiment, long-term treated cells had undergone 20 fewer population doublings compared with mismatch control and untreated cells. Moreover, exposure to $1 \mu \mathrm{mol} / \mathrm{L}$ GRN163L for 12 weeks reduced the telomere length from $5.5 \mathrm{~kb}$ to

\section{A}

Clonal efficiency of A549-Luc cells

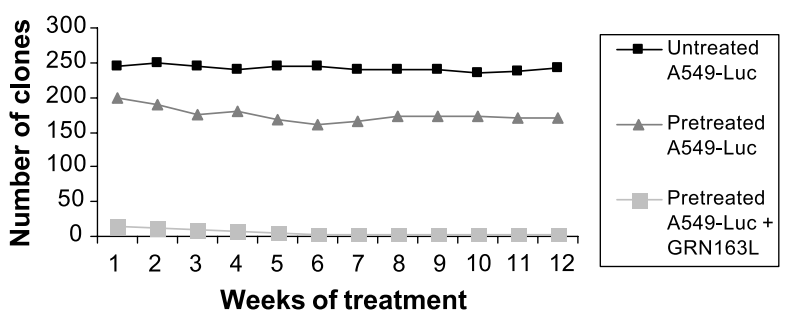

B

Soft agar assay

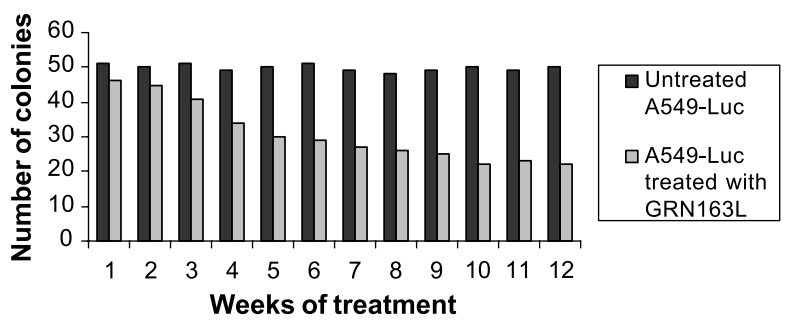

Figure 3. $A$, clonal efficiency of untreated A549-Luc cells (control) compared with pretreated A549-Luc cells with GRN163L ( $1 \mu \mathrm{mol} / \mathrm{L})$ in the absence and presence of additional GRN163L ( $1 \mu \mathrm{mol} / \mathrm{L})$ during cloning. $B$, colonies formed on soft agar by untreated A549-Luc cells (controls) and pretreated A549-Luc cells with GRN163L $(1 \mu \mathrm{mol} / \mathrm{L})$. Drug was present during the assay. 


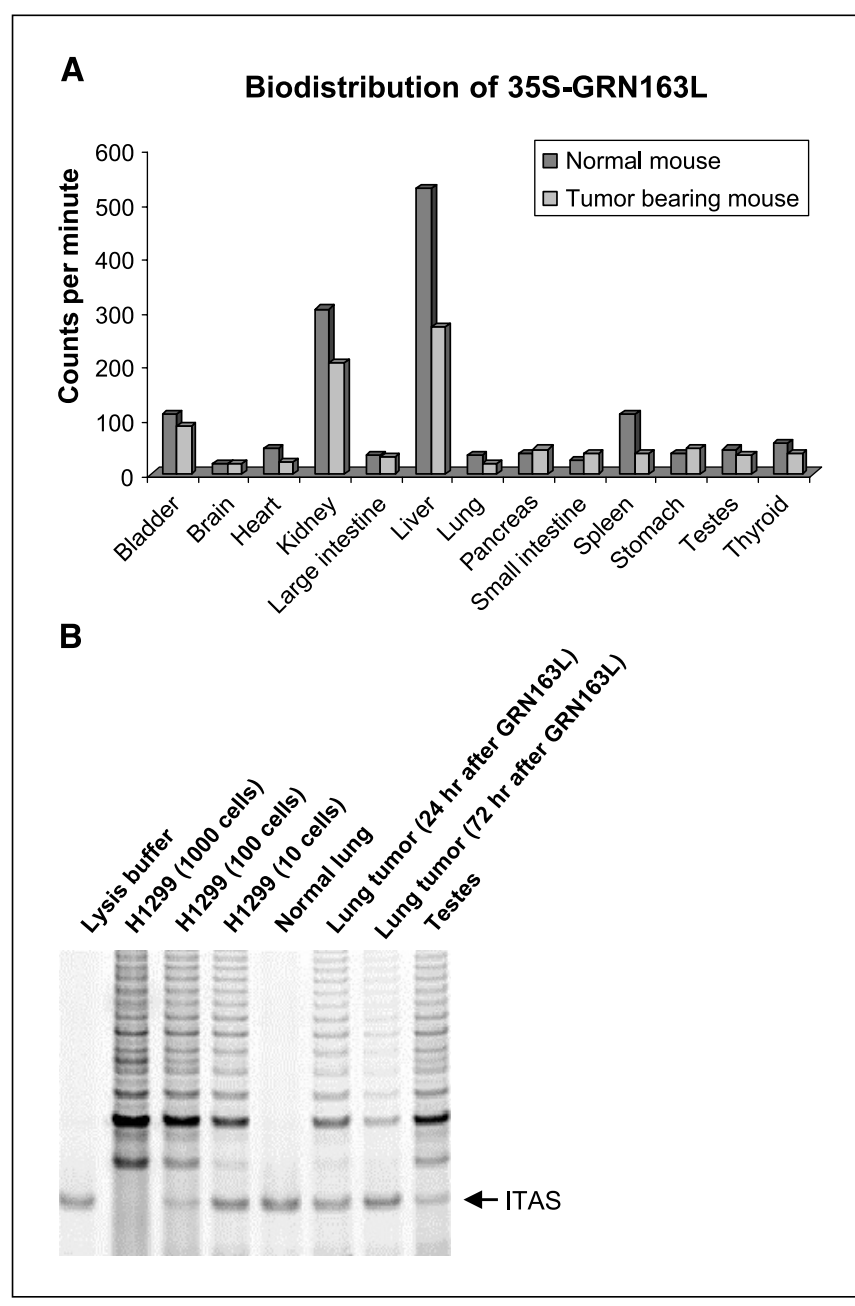

Figure 4. $A$, biodistribution of ${ }^{35} \mathrm{~S}-\mathrm{GRN} 163 \mathrm{~L}+\mathrm{GRN} 163 \mathrm{~L}$ in a healthy mouse and a mouse with lung tumors. B, TRAP activity after ${ }^{35} \mathrm{~S}-\mathrm{GRN} 163 \mathrm{~L}$

$(1 \mu \mathrm{Ci})-\mathrm{GRN} 163 \mathrm{~L}(5 \mathrm{mg} / \mathrm{kg})$ treatment. Lane 1 , lysis buffer (negative control); lanes 2-4, H1299 cells $(1,000,100$, or 10 cells); lane 5, normal lung; lane 6 , lung tumor (24 hours after GRN163L treatment); lane 7, lung tumor (72 hours after GRN163L treatment); lane 8, testes (positive control).

$3.5 \mathrm{kbp}$ as determined by TRF analysis (Fig. $1 B$ ). The growth of normal BJ fibroblasts was not affected by long-term GRN163L $(1 \mu \mathrm{mol} / \mathrm{L})$ treatment after up to 6 weeks of continuous treatment (data not shown).

Cells treated with GRN163L fail to form colonies in the clonal efficiency assay. It was surprising to observe that the A549-Luc cells failed to form colonies after relatively short treatment times with GRN163L $(1 \mu \mathrm{mol} / \mathrm{L}$, two doses total for 10 days). This was detected even after 1 week of pretreatment with GRN163L, when there is no detectable average telomeric shortening (Fig. $3 A$ ). The cells do attach to the cell culture dish but do not form easily visible colonies. These cells can proliferate again and form colonies when tested 2 weeks after GRN163L treatment is stopped (data not shown). These results indicate that A549-Luc cells lose the ability to form colonies in the presence of GRN163L and this effect may be related to yet unknown functions of telomerase that may be independent of protecting or extending telomeres.

Treatment with GRN163L results in loss of colony formation properties in soft agar. Because there is a general correlation between the tumorigenic potential of cells in vivo and their ability to grow in an anchorage-independent manner in vitro, growth in soft agar can be used as a surrogate in vitro tumorigenicity assay. After 4 to 5 weeks of GRN163L $(1 \mu \mathrm{mol} / \mathrm{L})$ treatment, the number of colonies formed was greatly reduced compared with untreated A549-Luc cells as shown by soft agar assays (Fig. 3B).

In vivo biodistribution of ${ }^{35} \mathrm{~S}$-labeled GRN163L in mouse tissues. Mice were sacrificed 24 and 72 hours after a single tail vein injection of ${ }^{35} \mathrm{~S}-\mathrm{GRN} 163 \mathrm{~L}(1 \mu \mathrm{Ci})+$ GRN163L $(5 \mathrm{mg} / \mathrm{kg})$. Various tissues were collected for drug distribution and TRAP assay. The highest concentration of label was found in liver, kidney, and bladder 72 hours after radiolabeled GRN163L administration. The levels of ${ }^{35} \mathrm{~S}-\mathrm{GRN} 163 \mathrm{~L}$ were lower in the excretory organs of the mice with lung tumor compared with the healthy mouse (Fig. 4A). Whereas there was no significant difference in drug accumulation in the control animal healthy lungs versus animals with lung tumors, systemic administration of ${ }^{35}$ S-GRN163L + GRN163L by tail vein reveals $\sim 2$-fold decrease the telomerase activity levels in the lung tumor samples after 72 hours of treatment compared with 24 hours of treatment as shown by TRAP assay (Fig. $4 B$ ).

In vivo antimetastatic effects of GRN163L on pretreated A549-luciferase cells in xenograft models. A549-Luc cells were treated with $1 \mu \mathrm{mol} / \mathrm{L}$ GRN163L every 3 days in vitro for 3 weeks and then $1 \times 10^{6}$ untreated control or GRN163L-treated cells were injected into the tail vein of each of eight nude mice. The treatment group $(n=4)$ was further treated with GRN163L ( $5 \mathrm{mg} / \mathrm{kg}$, i.p.) every 3 days for 3 weeks. Lung metastasis in the control group $(n=4)$ developed within 3 to 4 weeks after tumor cell challenge, whereas no tumor formation was detected in the GRN163L treatment group (Fig. 5A). The lungs of these eight mice were dissected and filled with India ink (15\%) by intratracheal instillation, the metastatic tumors were revealed as white nodules on the black lung surface following fixation in Fekete's solution (Fig. $5 B$ ), whereas the lungs of the treated group remained almost completely tumor free (Fig. $5 C$ ). The lungs were also analyzed by histopathologic examination (Fig. 5D). Only a few small tumors were seen in the animals treated with GRN163L.

In vivo antimetastatic effects of GRN163L on A549-luciferase cells without pretreatment in xenograft models. A549-Luc cells $\left(1 \times 10^{6}\right)$ were injected via the tail vein in nine nude mice. The animals were injected i.p. with nothing (control, $n=3$ ) or $5 \mathrm{mg} / \mathrm{kg}$ $(n=3)$, and $15 \mathrm{mg} / \mathrm{kg}(n=3)$ of GRN163L thrice per week for 3 weeks. The control and the treatment groups were imaged by LETS at the end of the treatment. The group treated with $5 \mathrm{mg} / \mathrm{kg}(n=3)$ formed smaller tumors than the control group $(n=3)$, whereas the animals treated with $15 \mathrm{mg} / \mathrm{kg}(n=3)$ did not form lung tumors (Fig. 6). Two weeks after the end of GRN163L administration, lung tumors began to grow in the treatment group, but these were smaller than in the controls. Importantly, mice treated i.p. with GRN163L for 3 weeks exhibited no evidence of toxicity, such as weight loss or abnormal behavior.

\section{Discussion}

Activation or up-regulation of telomerase is believed to be an important step in the progression of almost all human malignancies. GRN163L, a lipidated oligonucleotide thio-phosphoramidate is an hTR template antagonist that functions as a conventional 
competitive enzyme inhibitor. The oligonucleotide sequence $5^{\prime}$ TAGGGTTAGACAA- $3^{\prime}$ is complementary to a 13-nucleotide-long region partially overlapping and extending by four nucleotides beyond the $5^{\prime}$ boundary of the template region of hTR (39).

Oligonucleotide N3 $\rightarrow$ P5-thio-phosphoramidate (GRN163) was shown to inhibit telomerase activity with $\mathrm{IC}_{50}$ values of 0.5 to $5 \mathrm{nmol} / \mathrm{L}$ and 0.5 to $1.0 \mu \mathrm{mol} / \mathrm{L}$ with and without a lipid carrier such as LipofectAMINE in immortal HME50-E cells. Reduction of the cellular proliferation rate and telomeric shortening (3-1.9 kb), was achieved only with lipid-formulated thio-phosphoramidates, whereas unformulated thio-phosphoramidates (without lipid carrier) did not significantly change either cellular proliferation or the length of telomeres. Inefficient cellular uptake or intracellular distribution in the absence of lipid carrier may reduce the activity of thio- phosphoramidates (40). The addition of a lipid group to the oligonucleotide enhances the cellular uptake of the drug, resulting in an increase in its potency. Hence, we used a lipidated form of N3 $\rightarrow$ P5-thio-phosphoramidate (GRN163L) for our in vitro and in vivo experiments.

In the present study, the in vitro and in vivo effects of 13-mer palmitoyl N3 $\rightarrow$ P5-thio-phosphoramidates (GRN163L) on A549Luc cells were evaluated. Colony formation, soft agar growth, and growth of xenograft tumors in nude mice were used to test the tumorigenic potential of GRN163L-treated cells. We found that GRN163L alone without any transfection reagent inhibits telomerase activity of A549-Luc cells, and during the first 2 to 3 weeks of treatment does not significantly affect cell growth rates. With prolonged exposure to GRN163L ( $1 \mu \mathrm{mol} / \mathrm{L})$, a decrease in cell growth rate and progressive shortening of telomeres is
Figure 5. $A$, antimetastatic effects of GRN163L on pretreated A549-Luc cells. A549-Luc cells were treated every 3 days in vitro with GRN163L $(1 \mu \mathrm{mol} / \mathrm{L})$ for 3 weeks then $1 \times 10^{6}$ cells were tail vein injected into nude mice which were then treated every 3 days with $5 \mathrm{mg} / \mathrm{kg}$ GRN163L. B, lungs of the control group. $C$, GRN163L-treated group. Only a few small tumors were found in the treated group. $D$, histopathologic examination of one of the few microscopic lung tumors observed in a GRN163L animal.
A
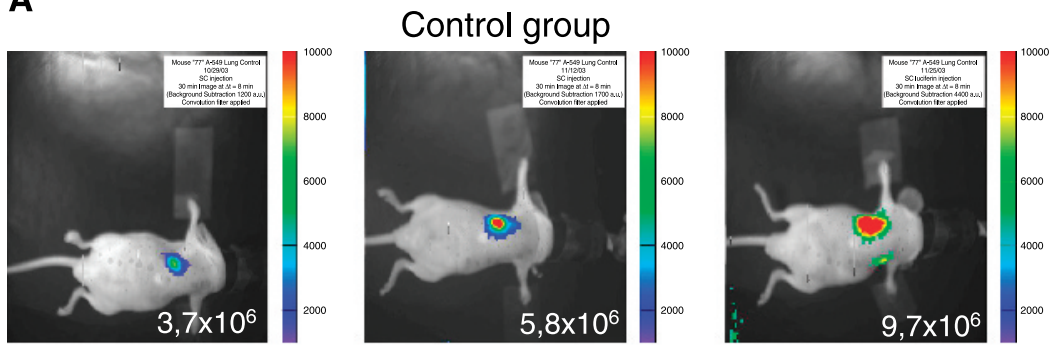

GRN163L treatment group (5 mg/kg)

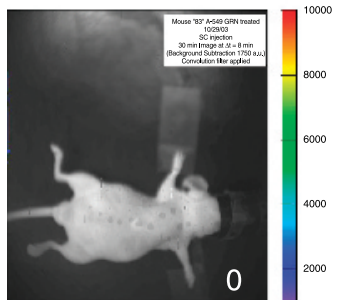

B

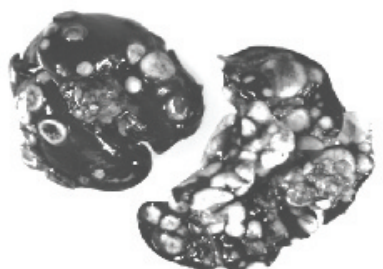

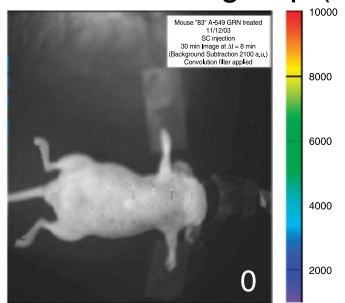

C
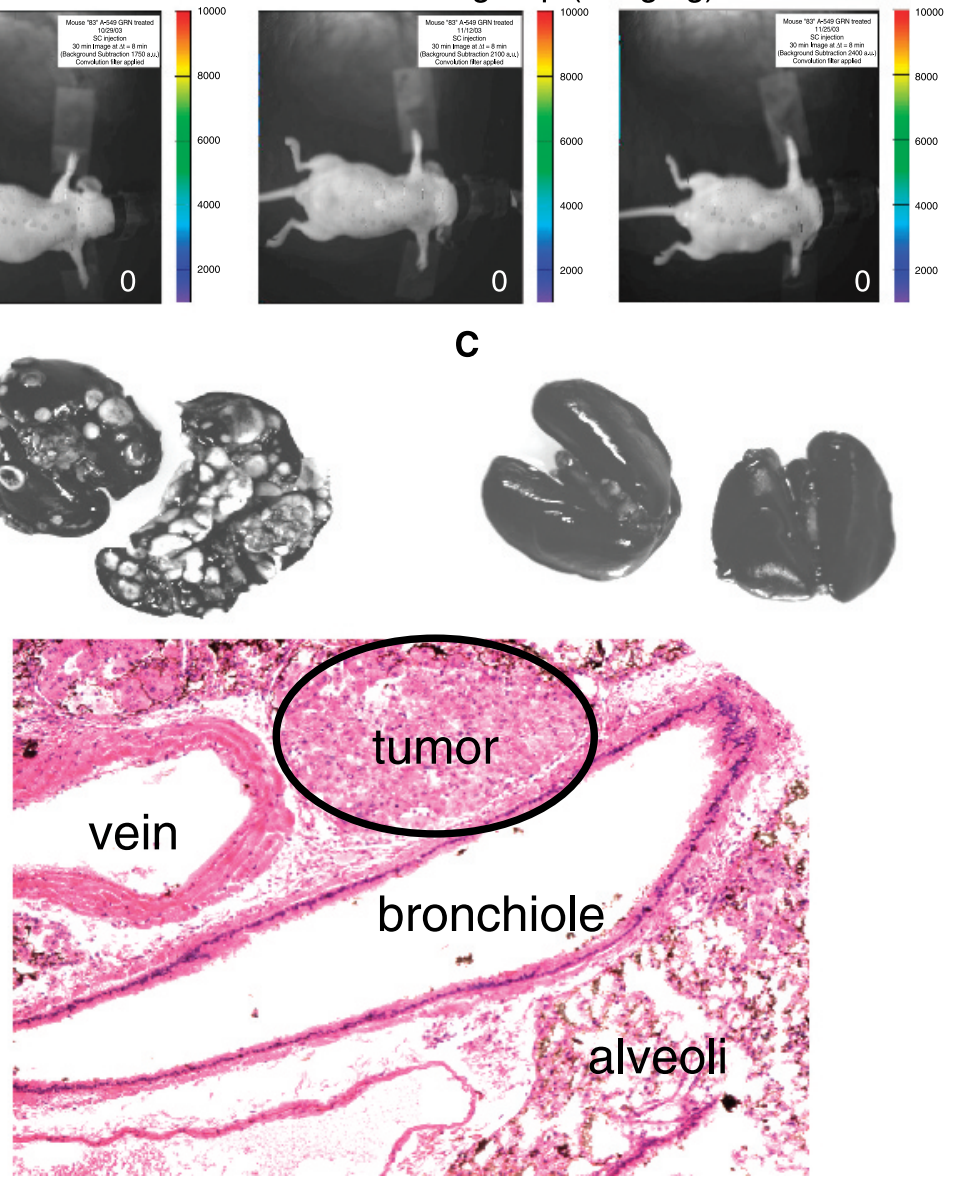


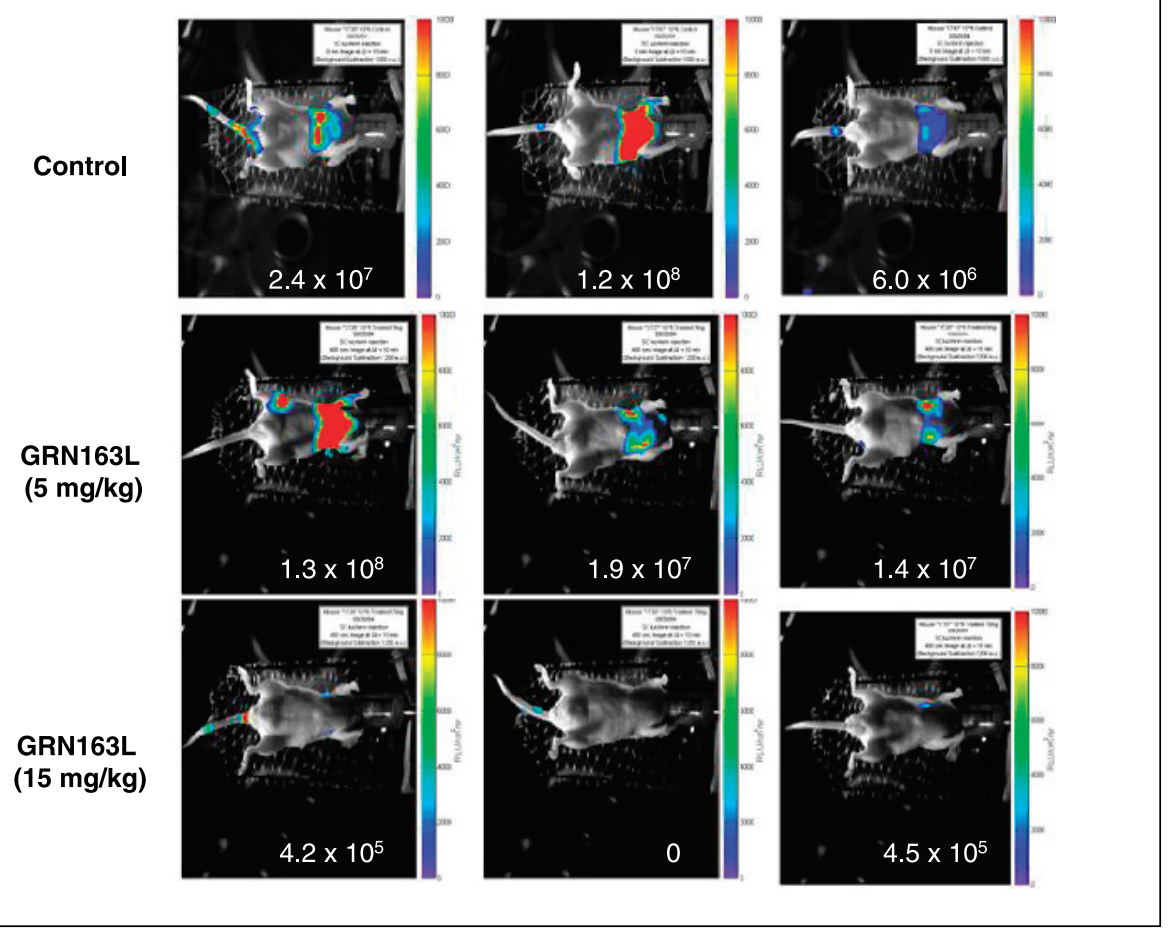

Figure 6. Antimetastatic effects of GRN163L on A549-Luc cells without pretreatment. A549-Luc cells $\left(1 \times 10^{6}\right)$ were injected via the tail vein in nine nude mice. The animals were injected i.p. with 0 $(n=3), 5 \mathrm{mg} / \mathrm{kg}(n=3), 15 \mathrm{mg} / \mathrm{kg}(n=3)$ of GRN163L thrice per week for 3 weeks. The quantitative light emission from each animal is indicated by the number in each panel. Animals were imaged 5 weeks after the end of the 3-week treatment period.

observed. The prolonged exposure to GRN163L required to induce growth arrest and reduction of telomere length suggest that these effects are induced by inhibition of telomerase because the mismatch control did not inhibit cell growth or reduce telomere length. Inhibition of telomerase activity was also observed using in vivo human lung tumor xenograft samples 72 hours after i.v. injection of ${ }^{35} \mathrm{~S}-\mathrm{GRN163L}(1 \mu \mathrm{Ci})$ along with GRN163L (5 mg/kg).

That A549-Luc cells lost their ability to form colonies in the presence of GRN163L within 1 week of GRN163L treatment was an unexpected result. At the same time, when tested after 2 weeks of terminating exposure to the inhibitor, the cells regained their ability to form colonies at the same rate as cells treated with mismatch oligonucleotides. One possible explanation to the observed effects is that GRN163L-induced telomerase inhibition may cause a chronic DNA damage response of an uncapped telomere of perhaps one or a few chromosome ends thus reducing the clonal efficiency of the tumor cells. There have been recent reports of effects of telomerase independent of telomere maintenance (41) including changes in gene expression of matrix metalloproteinases that play a key role in tumor invasion and/or metastasis.

Although inhibition of telomerase offers exciting therapeutic possibilities for the treatment of human cancers, there are some potential limitations of this approach, such as the engagement of an alternative lengthening of telomere mechanism that can lead to anti-telomerase treatment resistance. Additionally, antitelomerase therapy may be associated with efficacy delay because of the lag period between the initiation of anti-telomerase therapy and the onset of therapeutically beneficial effects $(42,43)$. The combination of telomerase inhibitors with existing chemotherapy or irradiation may produce more rapid effects and provide another approach for minimizing the lag phase (44). There are also indirect therapeutic approaches targeting telomerase such as suicide gene therapy and immunotherapy $(45,46)$, which would avoid the lag period required for telomere shortening before observation of cell growth arrest and death.

Several important issues need to be addressed before oligonucleotides become widely used specific pharmaceutical agents including increased thermodynamic stability of the complexes formed by the oligonucleotides with their targets, specificity of their interactions, enhancement of oligonucleotide resistance to enzymatic degradation, hydrolytic stability, bioavailability in cells and in animal models, favorable pharmacokinetics, and biodistribution in the targeted human tissues. Chemical structures of the potential therapeutic oligonucleotides, the proper choice of suitable and biologically important molecular targets, and delivery methods may play a crucial role in ensuring the success of oligonucleotide-based therapeutic approaches (32). This is the first report of beneficial effects of the telomerase inhibitor GRN163L as a therapeutic cancer treatment in an experimental animal model of lung tumor metastases, suggesting that lipidated N3 $\rightarrow$ P5-thio-phosphoramidate oligonucleotides may also provide useful therapeutic agents in clinical trials.

\section{Acknowledgments}

Received 4/9/2005; revised 5/30/2005; accepted 6/15/2005

Grant support: Tubitak and TEV (G.Z. Dikmen), the Cancer Imaging Program P20 (Pre-ICMIC), Harold Simmons Comprehensive Cancer Center Resource in Imaging, CA86354, Geron Corp. (Menlo Park, CA), and Lung Cancer Specialized Programs of Research Excellence grant P50 CA75907.

The costs of publication of this article were defrayed in part by the payment of page charges. This article must therefore be hereby marked advertisement in accordance with 18 U.S.C. Section 1734 solely to indicate this fact.

We thank Daria Zielinska and Krisztina Pongracz for their help with preparation of oligonucleotides used in this study and the Cancer imaging group (Ralph Mason, Peter Antich, Edmond Richer, Bob Bollinger, and Allen Harper) of the University of Texas Southwestern for assistance with animal imaging studies. 


\section{References}

1. Shay JW, Roninson IB. Hallmarks of senescence in carcinogenesis and cancer therapy. Oncogene 2004;23: 2919-33.

2. Holt SE, Wright WE, Shay JW. Multiple pathways for the regulation of telomerase activity. Eur J Cancer 1997; 33:761-6.

3. Greider CW, Blackburn EH. Telomeres, telomerase and cancer. Sci Am 1996;274:92-7.

4. Mergny JL, Riou JF, Mailliet P, Teulade-Fichou MP, Gilson E. Natural and pharmacological regulation of telomerase. Nucleic Acids Res 2002;30:839-65.

5. Roth A, Vercauteren S, Sutherland HJ, Lansdorp PM. Telomerase is limiting the growth of acute myeloid leukemia cells. Leukemia 2003;17:2410-7.

6. Levy MZ, Allsopp RC, Futcher AB, Greider CW, Harley $\mathrm{CB}$. Telomere end-replication problem and cell aging. J Mol Biol 1992;225:951-60.

7. Counter CM, Avilion AA, LeFeuvre CE, et al. Telomere shortening associated with chromosome instability is arrested in immortal cells which express telomerase activity. EMBO J 1992;11:1921-9.

8. Wright WE, Shay JW. Telomere dynamics in cancer progression and prevention: fundamental differences in human and mouse telomere biology. Nat Med 2000;6: 849-51.

9. Rubio MA, Davalos AR, Campisi J. Telomere length mediates the effects of telomerase on the cellular response to genotoxic stress. Exp Cell Res 2004;298:17-27. 10. Kim NW, Piatyszek MA, Prowse KR, et al. Specific association of human telomerase activity with immortal cells and cancer. Science 1994;266:2011-5.

11. Shay JW, Bacchetti S. A survey of telomerase activity in human cancer. Eur J Cancer 1997;33:787-91.

12. Wynford-Thomas D. Cellular senescence and cancer. J Pathol 1999;187:100-10.

13. Yasumoto S, Kunimura C, Kikuchi K, et al. Telomerase activity in normal human epithelial cells. Oncogene 1996;13:433-9.

14. Asai A, Oshima Y, Yamamoto $Y$, et al. A novel telomerase template antagonist (GRN163) as a potential anticancer agent. Cancer Res 2003;63:3931-9.

15. Naasani I, Seimiya H, Tsuruo T. Telomerase inhibition, telomere shortening, and senescence of cancer cells by tea catechins. Biochem Biophys Res Comm 1998;249:391-6.

16. Naasani I, Seimiya H, Yamori T, Tsuruo TF. J.5002: a potent telomerase inhibitor identified by exploiting the disease-oriented screening program with COMPARE analysis. Cancer Res 1999;59:4004-11.
17. Damm K, Hemmann U, Garin-Chesa P, et al. A highly selective telomerase inhibitor limiting human cance cell proliferation. EMBO J 2001;20:6958-68.

18. Hisatake J, Kubota $T$, Hisatake $Y$, Uskokovic $M$ Tomoyasu S, Koeffler HP. 5, 6-trans-16-ene-vitamin D3 a new class of potent inhibitors of proliferation of prostate, breast, and myeloid leukemic cells. Cancer Res 1999;59:4023-9.

19. Neidle S, Harrison RJ, Reszka AP, Read MA. Structureactivity relationships among guanine-quadruplex telomerase inhibitors. Pharmacol Ther 2000;85:133-9. 20. Hurley LH, Wheelhouse RT, Sun D, et al. Gquadruplexes as targets for drug design. Pharmacol Ther 2000;85:141-58.

21. Gomez D, Aouali N, Renaud A, et al. Resistance to senescence induction and telomere shortening by a Gquadruplex ligand inhibitor of telomerase. Cancer Res 2003;63:6149-53.

22. Hahn WC, Stewart SA, Brooks MW, et al. Inhibition of telomerase limits the growth of human cancer cells. Nat Med 1999;5:1164-70.

23. Glukhov AI, Zimnik OV, Gordeev SA, Severin SE. Inhibition of telomerase activity of melanoma cells in vitro by antisense oligonucleotides. Biochem Biophys Res Commun 1998;248:368-71.

24. Wan MSK, Fell PL, Akhtar S. Synthetic 2-O-methylmodified hammerhead ribozymes targeted to the RNA component of telomerase as sequence-specific inhibitors of telomerase activity. Antisense Nucleic Acid Drug Dev 1998:8:309-17.

25. Kondo Y, Komata T, Kondo S. Combination therapy of 2-5A antisense against telomerase $\mathrm{RNA}$ and cisplatin for malignant gliomas. Int J Oncol 2001;1: 1287-92.

26. Norton JC, Piatyszek MA, Wright WE, Shay JW, Corey DR. Inhibition of human telomerase activity by peptide nucleic acids. Nat Biotechnol 1996;14 615-9.

27. Gryaznov S, Asai A, Oshima Y, et al. Oligonucleotide $\mathrm{N} 3^{\prime} \rightarrow \mathrm{P} 5$ '-thio -phosphoramidate telomerase template antagonists as potential anticancer agents. Nucleosides Nucleotides Nucleic Acids 2003;22:569-73.

28. White LK, Wright WE, Shay JW. Telomerase inhibitors. Trends Biotechnol 2001;19:114-20.

29. Chen Z, Koeneman KS, Corey DR. Consequences of telomerase inhibition and combination treatments for the proliferation of cancer cells. Cancer Res 2003;63 5917-25.

30. Gryaznov SM, Winter H. RNA mimetics: oligoribonucleotide $\mathrm{N}^{\prime} \rightarrow \mathrm{P}^{\prime}$ phosphoramidates. Nucleic Acids Res 1998;26:4160-7.
31. Gryaznov SM, Banait NS. DNA and RNA analogues: oligonucleotide phosphoramidates with bridging nitrogen. Expert Opin Ther Patents 2002;12:543-58.

32. Eglia M, Gryaznov SM. Synthetic oligonucleotides as RNA mimetics: 2'-modified RNAs and $\mathrm{N} 3^{\prime} \rightarrow \mathrm{P}^{\prime}$ phosphoramidates. Cell Mol Life Sci 2000;57:1440-56.

33. Pruzan R, Pongracz K, Gietzen K, Wallweber G, Gryaznov S. Allosteric inhibitors of telomerase: oligonucleotide N3' $\rightarrow \mathrm{P} 5$ '-phosphoramidates. Nucleic Acids Res 2002;30:559-68.

34. Pongracz K, Gryaznov S. Oligonucleotide $\mathrm{N} 3^{\prime} \rightarrow \mathrm{P} 5$ thio-phosphoramidates: synthesis and properties. Tetrahedron Lett 1999;40:7661-4.

35. Gryaznov S, Pongracz K, Matray T, et al. Telomerase inhibitors: oligonucleotide phosphoramidates as potential therapeutic agents. Nucleosides Nucleotides Nucleic Acids 2001;20:401-10.

36. Damstrup L, Poulson HS. Review of the curative role of radiotherapy in the treatment of non-small cell lung cancer. Lung Cancer 1994;11:153-78.

37. Grili R, Oxman AD, Julian JA. Chemotherapy for advanced non-small cell lung cancer: how much benefit is enough? J Clin Oncol 1993;11:1855-71.

38. Bunn PA, Shepherd FA, Sandler A, et al. Ongoing and future trials of biologic therapies in lung cancer. Lung Cancer 2003:41:175-86.

39. Ozawa T. Antitumor effects of specific telomerase inhibitor GRN163 in human glioblastoma xenografts. Neuro-oncol 2004;6:218-26.

40. Herbert BS, Pongracz K, Shay JW, Gryaznov SM Oligonucleotide $\mathrm{N} 3^{\prime} \rightarrow \mathrm{P} 5^{\prime}$ phosphoramidates as efficien telomerase inhibitors. Oncogene 2002;21:638-42.

41. Koyama S. Enhanced cell surface expression of matrix metalloproteinases and their inhibitors, and tumor-induced host response in progression of human gastric carcinoma. Dig Dis Sci 2004;49:1621-30.

42. Bechter OE, Zou Y, Walker W, Wright WE, Shay JW Telomeric recombination in mismatch repair deficien human colon cancer cells after telomerase inhibition. Cancer Res 2004;64:3444-51.

43. Bechter OE, Shay JW, Wright WE. The frequency of homologous recombination in human ALT cells. Cell Cycle 2004:3:547-9.

44. Mokbel K. The evolving role of telomerase inhibitors in the treatment of cancer. Curr Med Res Opin 2003;19: $470-2$

45. Vonderheide RH. Telomerase as a universal tumorassociated antigen for cancer immuno-therapy. Oncogene 2002;21:674-9.

46. Shay JW, Wright WE. Telomerase: a target for cancer therapeutics. Cancer Cell 2002;2:257-65. 


\section{In vivo Inhibition of Lung Cancer by GRN163L: A Novel Human Telomerase Inhibitor}

Z. Gunnur Dikmen, Ginelle C. Gellert, Shalmica Jackson, et al.

Cancer Res 2005;65:7866-7873.

Updated version Access the most recent version of this article at:

http://cancerres.aacrjournals.org/content/65/17/7866

Cited articles This article cites 46 articles, 8 of which you can access for free at:

http://cancerres.aacrjournals.org/content/65/17/7866.full\#ref-list-1

Citing articles This article has been cited by 21 HighWire-hosted articles. Access the articles at:

http://cancerres.aacrjournals.org/content/65/17/7866.full\#related-urls

\section{E-mail alerts Sign up to receive free email-alerts related to this article or journal.}

Reprints and To order reprints of this article or to subscribe to the journal, contact the AACR Publications Subscriptions Department at pubs@aacr.org.

Permissions To request permission to re-use all or part of this article, use this link http://cancerres.aacrjournals.org/content/65/17/7866.

Click on "Request Permissions" which will take you to the Copyright Clearance Center's (CCC)

Rightslink site. 